\title{
Ethnography and the politics of absence
}

\author{
RONALD G. SULTANA \\ University.of Malta
}

By speech, silence becomes the centre and principle of expression, its vanishing point. Speech eventually has nothing more to tell us: we investigate the silence, for it is the silence that is doing the speaking.

Macherey (1978, p. 86)

\section{Introduction}

This article is about the silences that often are registered but not so often highlighted and analysed with the anthropological tools of the ethnographer, referring as these do to the empirical world that can be captured. While there is abundant literature that helps the ethnographer refine the technical aspects of the writing of the narrative, it has been only recently that the political implications behind the epistemology and ontology of ethnography as a research strategy have been addressed in any depth.

Rather than, therefore, looking at ways of improving the collection of data, this paper will consider an aspect that hitherto has been largely ignored in ethnography. The focus will be on what the ethnographic text leaves unsaid. A number of silences will be identified with reference to the process, content, and political effectiveness of ethnographic narratives, although it will be argued that these silences or gaps are not all of the same kind, and that some rather than others are more promising in the construction of radical educational theory and practice.

Qualitative research, in itself, seems little concerned with the absences that frame (or are at the heart of) the narrative it weaves - the "reality" it claims to reflect - or the process through which the phenomena are represented. The roots of ethnography are to be found deeply embedded in a regime of realism, inasmuch as it sets out to represent the empirical world that "is." There is, indeed, a danger that the ethnographic narrative entraps the writer and reader in this nominal positivist world: details of what happened, who spoke, what was said. It is the dictatorship of data, from which concepts and generalizations arise, "faithfully" representing the particulars from which they have been abstracted. In these positivistic moments that govern ethnographic representation, silence has little value and can only be regarded negatively - an empty absence which, in a matter of time, could and should become full of words.

Not so for the radical ethnographer who approaches phenomena in the spirit of Nietzsche or Marx or the critical theorists: as dangerous illusions, where the "what is not" is infinitely more important than the "what is." The non-positivist accords silences, gaps, and absences a special and prestigious place in his/her theoretical engagement with the world and looks to them for clues that will lead not only to reflexivity but to praxis. The "real" is subjected to problemization, for it is 
"historically produced in the course of conflicts and struggles or collective life. Realism stabilizes and naturalizes the objects and apparatuses of perception and knowledge" (Wexler, 1987, p. 85). In purporting to tell us "what happened," realistic ethnography presents itself as a complete narrative. But the sum of the details of the ethnographic text never can be complete and is riven with contradictions and absences, for they too, in Lukacs's (1971) words, have to be understood "as aspects of a totality, i.e., as the aspects of a total social situation caught up in the process of historical change" (p. 162).

How, then, to deal with the incompleteness of a text? This question does not imply that ethnographies somehow should be "complete texts" that "tell all there is to tell." As Tyler (1987) argues "Every attempt will always be incomplete, insufficient, lacking in some way, but this is not a defect since it is the means that enables transcendence. Transcendence comes from imperfection, not from perfection"' (p. 136). But incompleteness does pose a challenge to the critic whose task is similar to that of a therapist, that is, "not to cure or complete [the text]; but to explain why it is as it is" (Eagleton, 1976, p. 92). The problem with this kind of exercise, however, is that the silences and absences easily can become the repository for all that the critic projects.

So do we commit ourselves to nihilism when we privilege silence? Quite the contrary - it is to discover, if not the grand narratives, at least the master narratives (Giroux, 1988) that shape detail. It is to balance delicately the more emancipatory moments of postmodernist thought with that tradition that allows not only critique but also utopian dreaming. To privilege silence is to realize that text is ideology inasmuch as it attempts to reflect the world in a coherent and totalitizing manner. It is to admit, in the spirit of modern philosophy, the limits of reason and thus to open the way for the valuing of silence, unknown and unrespected by idealist and positivist philosophy alike. The privileging of silence is a strategy for recognizing the status of the ethnographic text as a construct, and hence to render it immediately a candidate for deconstruction.

In order to accept this interpretation of silence, however, it also is necessary to presuppose the existence of some form of master narrative that weaves the tale into some version of a totalizing vision - a point well made by McLaren (1988) when he argues in favour of an "arch of social dreaming ... the conquest of a vision of what the total transformation of society might mean" (p. 74). But this would seem to imply that silence and gaps always are ideological, which would mean in practice that simply by having the master narrative at hand, and using it as a template on the presenting narrative, will quickly show up the ideologically significant silences, nowidentifiable in confrontation with the "whole story," as it were. It is therefore important at this point to construct a grammar of silence, to have some guidelines to mark a path through the impossibly difficult task of finding our way through the maze of silence. As Macherey (1978) - the Althusserian theorist of the "absent centre" in literary texts - argues, we need to ask if the silence denotes

a true absence, or is it the extension of a half-presence? ... Will it be the pillar of an explanation or the pretext for an interpretation?... Can we say that this silence is hidden? What is it? A condition of existence - point of departure, methodological beginning - essential foundation - ideal culmination - absolute origin which lends meaning to the endeavour? Means or form of connection? Can we make this silence speak? What is the unspoken saying? What does it mean? To what extent is dissimulation a way of speaking? Can something that has hidden itself be recalled to our presence? Silence as the source of expression. Is what I am really saying what I am not saying? Hence the main risk run by 
those who would say everything. After all, perhaps the work is not hiding what it does not say; this is simply missing. (pp. 82, 85-86)

How, then, are we to distinguish what an ethnographic narrative cannot say, refuses to say, and simply does not say? And do we develop an inverted ethnographic method by measuring silences, whether acknowledged or unacknowledged? One way of working towards the resolution of these questions is to consider the various types of silences that can be attributed to ethnography. I will do this in the next section of this paper, referring critically to an ethnographic study that I carried out in 1986 (Sultana, 1987, 1992 ) in order to contextualize and illustrate the points that I make.

\section{Ethnography and the semiotics of silence}

In the identification of some of the more important silences within ethnographic texts, it would be useful to classify the absences and gaps along certain criteria. I use two guidelines in developing this classificatory system, the first being organizational, and the second political. While the concern of the former is to systematize the presentation of ideas, the latter interest is the political reciphering of these silences in favor of transformative action in the world. In the interest of systematic presentation and clarity, I will number the variety of absences I identify, while in no way claiming that there are no gaps within the very text that I myself produce. These absences will refer to (a) process, (b) content, and (c) political ontology of ethnographic texts. The concluding section of the paper will deal with the politics of silence, pointing towards new ways of making that silence speak in favor of a more just and humane world.

\section{Ethnographic process and silence}

The doing of ethnography, the very choice of qualitative research as a tool, itself can be framed by a number of silences. Tyler (1985) and Clifford and Marcus (1986) argue that since ethnography inscribes culture in discourse rather than merely describes it, it is the end of description, for the very act of writing binds politics and poetics. The choice of ethnography, in this sense, needs to be justified as much as what one does with - and how one writes - ethnography. Many, including Gitlin, Siegel, and Boru (1989), have highlighted the need to expose the formative influence behind the silence of the researcher, the "author-as-author" who often constitutes himself as "author-as-fieldworker," inviting the reader into the realm of narrative realism where everything there is to tell is narrated in a neutral fashion. It is because the researcher edits himself/herself out of the text that we often get so little information on such details as the researcher's expectations and presuppositions, or the surprises that were encountered in the field.

Not that the researcher can, in any real manner, suspend the biases that are at work. Rather, as in Gadamer's (1979) discussion of modern hermeneutics, research should be characterized by a reflexivity that enables us to understand the possibility of a multiplicity of viewpoints and "to respond to opposing arguments by a reflection which deliberately places us in the perspective of the other" (p.110). But, as Gitlin et al. (1989) argue, "It is impossible for the researcher to understand the 'subject' unless she/he enters into a dialogue with the 'subject' aimed at mutual understanding"' (p. 243). They go on to point out the contradiction by those researchers who claim to be 
"concerned with emancipatory change" and who therefore are "interested in contesting relations of domination," but who in fact "use a method which reproduces the type of relations they so despise" (p. 249).

Hence, in considering the silences and absences in the process of ethnographic research, it is precisely this possibility of gaining insight from others that often is precluded, for the emphasis, as McLaren (1990) points out, is on doing research on, not with, others. It is this kind of approach that stresses, for instance, the need to keep the researcher's opinions and perspectives privy from those being "researched." In carrying out my ethnographic study of three school communities in New Zealand, where the focus was the gauging of the school-to-work messages given by the form, content and process of the schools and the kinds of reception that the students afforded these messages, I often was caught in a frustrating and ideologically contradictory position. Students, for instance, would tell me of sexist or racist attitudes and comments of teachers, but I would feel reluctant to confront the school communities with these criticisms, afraid that such early feedback somehow would change the nature of the schools, and that I would go against the ultimately positivist principle of introducing extraneous "variables" into the research (laboratory?) field.

The attempt not to jeopardize the research by trying hard not to change the situation by acting on it led, of course, to a number of problems. The maintenance of an "objective front" with teachers, for instance, certainly reinforced the subordinate positions of teachers as "researched." The attempt at withholding also creates some insincerities which I found difficult to deal with, both at the ethical and the political level. For how can one possibly be effective in challenging teachers to regard their practice critically if, in our own work as researchers, we resort to underhand ways in order to satisfy our appetite for yet more detail?

It is perhaps for this reason that the point of view of those researched too often is not heard within the ethnographic report. Critics on the left, such as Reynolds (1980-1981, p. 84), have in fact taken interactionist ethnographic accounts to task for canonizing the perspectives of the social members in the explanation of social phenomena, to the exclusion of the arbitration of the intellectual or social scientific class. But radical researchers too often have gone to the other extreme and have been too ready to ignore, for instance, the cultural constraints under which teachers labor, leading to "teacherbashing" accounts that effectively jeopardize any interaction between researchers (who "know it all") and workers in schools. While it does make sense to criticize ethnographies that are influenced exclusively by phenomenological and ethnomethodological traditions, it needs to be accepted that the sense-making practices that individuals utilize to interpret their world are to be given importance and that, for epistemological and practical political reasons, these should be "triangulated" with other possible accounts, including those of the ethnographer who positions herself/himself within a particular ideological discourse.

Another silence that structures the creation of ethnographic texts is the rather politically naive view that these "anatomies of detail" (Wexler, 1987, p. 85) somehow will be used automatically in favour of those with whom the researcher has political sympathies. Few researchers have outlined the danger that their ethnographies will not become yet another of the panoptic erections in service of the governing episteme of our times to surveil, discipline, and punish. The consideration of this became real for me when, in the course of feedback to staff in the school communities I had researched, I produced vivid descriptions of the resistant strategies developed by Maori students, with the intention of encouraging a debate on the need for cross-cultural schooling. My 
hope that this would lead schools and teachers to become more sensitive to the realities that groups of students experience in their daily lives often was co-opted, however, and the data reinterpreted in terms of another goal, that is, that of better controlling what was often considered to be pathological behavior. There always is a risk, therefore, that the progressive agendas of ethnographers are hijacked and their labor appropriated for conservative, if not oppressive ends.

Content, silence, and the selective tradition

Ethnography as realist text seeks to reflect the empirical world that it focuses on, and in its more emancipatory moments it does so in a critical manner. While for some time the tradition has been to give pride of place to "thick description," the real promise of ethnography as a transformative tool is fulfilled when it becomes theoretically embedded and when it, therefore, tries to recover the silenced context, the conditions and the relations in the light of which phenomena need to be apprehended. As West (1984) has argued so well, it has become possible to situate particular ethnographies within wider structural accounts, and this synthesis of phenomenon and form is possible not only at the epistemological level but, as we shall see in the next section, also can be articulated at the political level (Sharp, 1982).

Such a synthesis is particularly promising in order to make sense of the gaps in narratives that are to be found within institutions such as schools. Gramsci's notion of "hegemony" - as well as Williams's (1976) related insight that one of the key ways through which control is maintained is through the "selective tradition" - are particularly useful theoretical tools in our attempt at analysing what can be referred to as the "logic of nonevents." As Eagleton (1976) has argued, "ideology is present in the text in the form of its eloquent silences" (p. 89). In other words, hegemony is possible because silence is privileged in a reactionary manner, and ethnography attains its radical promise when, rather than dancing to the music it hears, it listens intently to that silence, making that silence speak volumes in favor of the powerless and oppressed.

There is an important kind of silence with which a radical ethnography should engage. This is the silence of the context in which the contents of the text is framed, what Bisseret (1979) calls "the referent." Silence thus constitutes part of the metaphysics of presence and, in contrast to the more anarchic moments of postmodernism, depends on "something being outside and anchoring the symbolic relations of the text" (Wexler, 1987, p. 135). The referent functions by attributing lack or absence to those who do not possess the qualities attributed to others holding dominant positions. In the case of my own study, the hidden referent nearly always was the capitalist world of work as it is, and to which the students constantly and unproblematically were asked - coerced even - to refer to in their preparation for transition to "the" world of work (Sultana, 1988, 1989, 1990). This is why my own ethnography is replete with references to that which was not said, and while, on the surface, such writing seems to contradict the nature of ethnographic writing, any radical researcher working within this mode constantly has to appeal to that which is not there. Indeed, what I prefer to call "inverted ethnography" is the only way that one can subvert the positivistic regime of realism that still lingers on in this research strategy. Those who do not read the silences in a text

read from the same ideological framework, share the same repressions, and take 
for granted the same silences.... It is still only by distancing ourselves from the familiar modes of representation that we can expect to identify the areas on which ideology is silent. (Belsey, 1980, p. 137)

The selective tradition needs to be exposed and explored in any ethnography that claims for itself radical and transformative intentions. For the curriculum narrative revels in common-sense ideas that express and encapsulate the requirements of the dominant class. In my own study, a curriculum that purported to teach about the world of work prepared students to accept that world uncritically, often failing to problematize key issues such as wealth, power, oppression and exploitation, the wage relationship, class, gender, and race relations on the work-force, and collective struggle on the part of workers through trade unions. In such instances, silence is a key element in the discourse made available to students, having an ideological function inasmuch as it conceals the power relations that structure the content and process of the educational encounter.

Not all silences in the content of the text are ideological in the sense developed above. There are meso (institutional) and micro (classroom) as well as macro contexts that explain why some things are left unsaid (McNeil, 1987), though, this having been said, the point can still be made that the resulting silence can function in favor of the reproduction of the wider social formation. In my study, the silence of teachers on trade union matters did have an ideological function, but the context of the absence of messages on workers' movements often was motivated by a fear of conflict in the classroom. Anxiety that different opinions about unions might lead to classroom conflict led many teachers to adopt "survival strategies" to ensure their own comfort rather than educational ends (Hargreaves \& Woods, 1984).

But this is not in itself a sufficient explanation of the "micro-dynamics" of silence. Remaining with the example of messages about trade unions, it becomes clear that classroom dynamics can interrelate with ideological and macro reasons for the privileging of one silence over another. Those teachers who were afraid of conflict also were those whose ideological positions were most obviously bourgeois, who would, for example, become hostile if someone suggested to them that they belonged to a "teachers' trade union" rather than a "professional association." On the other hand, those who did break the silence on trade unions were those who, like technical teachers, had participated at some stage in productive work and who had experienced first hand capitalist relations of production and therefore had become politicized in favor of collective struggle and change.

\section{The political ontology of ethnography}

The problem that needs to be addressed here is the silence that reigns over the effectiveness of ethnographic research strategies in bringing about change in school communities and in educational policy making, if not, as sometimes is claimed even more ambitiously, in the wider social sphere. Some researchers and methodologists have given this issue some attention, and Pollard (1984), for instance, has argued that it is perhaps realistic to expect ethnography to have more impact at the micro level because of the nature of ethnographic work, for it enhances the possibility that actors in schools can make the movement from unexamined practical consciousness to the more critical self- and system-awareness of 'discursive consciousness'" (Giddens, 1976).

All this is acceptable, except that there have been few ethnographic studies that 
have told the readers much about the effectiveness of their study in bringing about change in any progressive direction. We often are presented with richly detailed descriptions, but once the narrative ends, the implicit assumption is that the readers (presumably the teachers and administrators of the school communities researched would be among them) somehow will improve their practice just by reflecting on it. Change will follow, it is implied, after consciousness has been raised. But does change follow? This question applies equally to the institutional and classroom levels as it does to the macro societal level. For ethnography often has been justified on the grounds of its political effectiveness. Shipman (1984) for instance, in a paper on ethnography and public policy, describes policy-makers as "hungry for evidence," and he regards ethnographic work as having a clear potential role by virtue of the inadequacies of previous quantitative work. Sharp (1982) has claimed that theoretically embedded ethnography has a political rationale, since

a scientific political practice requires knowledge of the fissures, ruptures, and contradictions in capitalism's mode of appearance which guide political and pedagogical work. Ethnography can offer insight concerning the points at which politicization is possible, feasible, and productive of greater awareness and concerning the processes through which this could be achieved. (p.60)

But while such political aspirations speak with a "language of possibility" about establishing more equitable and democratic social arrangements within and outside school, ethnographers on the left have to be more specific about their effectiveness in bringing about such progressive change. There have been too many ethnographies that conclude with a rousing appeal about the resistances and contestations, as well as the contradictions and systemic fissures identified by the ethnographer, while one is left almost entirely in the dark about whether these spaces, these cracks in the structure, actually do modify, if not radically transform, the world in favor of progressive ends.

In my study, there were varied responses by teachers and school principals, as well as boards of governors, to feedback sessions about my ethnographic narrative. At one level these responses were quite positive: it was gratifying to see teachers acknowledge the damaging effects of structures, curricula, and pedagogies that they promoted unproblematically in schools and to engage with them in an attempt to come up with alternative, more transformative modes of practice. However, four years following that research, I really wonder whether it has made any real difference in the structures and practices of those schools. But there is, in the tradition of educational ethnographic research, hardly any mention of the frustration such as I felt when, after spending so much time, money, and effort in carrying out research in those schools, I receive letters from friends who tell me that things have not really changed at all. Assuming for a moment that as a researcher I had all the technical details right (in terms of using the available tools effectively), then the problems that need to be confronted are whether we still have to develop a theory of how an audience changes itself (i.e., does consciousness-raising work?) or if the tool, that is, ethnography itself, is inadequate.

That the latter is probable emerges in Burbules's (1986) echoing of some of the concerns raised above, when he points to the need to move from description and analysis to active involvement within school communities. In the light of the issues raised throughout this paper, therefore, future educational researchers should move away from merely describing school life to promoting specific versions of it, versions that have been identified as being more equitable and democratic than the ones currently being engendered. In other words, the radical researcher would be involved 
in a sort of Freirian pedagogy - often advocated for teachers by radical researchers where she or he highlights various democratic and emancipatory voices, introducing new themes that heighten the chances for a truly critical education to occur. As Burbules (1986) notes, this is a crucial theoretical and political shift because it supplants the attempt to study and understand, somewhat dispassionately, the prospects for school reform in favor of advocating such reform, insisting on its possibility and becoming actively involved in making the possible probable.

\section{Conclusion}

There is, of course, great skill in the ethnographer's depiction of "life." The point of this paper has been that the real genius of the radical researcher will be to transform that "life" to come closer to a democratic vision. This is no easy task, for a number of reasons, some of which are very practical. It is doubtful whether the bureaucracies we call "schools" will allow any person to function inside the institution who has the explicit aim of bringing about change. The whole point of bureaucracies is systempreservation.

But it is incorrect to pursue a strategy, such as descriptive ethnography, which, while satisfying, indeed gratifying, our "need" to know, is largely ineffective in promoting transformation. The method argued in favor of in this paper - what is referred to as "inverted ethnography" - privileges silences because of the contention that the more substantial is to be found in that absence. We thus (actually or figuratively) develop a sign to highlight certain ideological silences, much as during the Renaissance mathematicians developed " 0 " (zero) as "a sign about signs, a meta-sign whose meaning is to indicate, via a syntax which arrives with it, the absence of certain other signs" (Rotman, 1987, p. 1). Since "ideology exists because there are some things which must not be said" (Eagleton, 1976, p. 90), "inverted ethnography" can do very little that is more radical than actually to dare to voice the unsaid. Thus, radical ethnography can shed its subservience to the regimes of realism in order to become a meditative and reflexive vehicle "because we come to it neither as to a map of knowledge nor as a guide to action, nor even for entertainment. We come to it as the start of a different kind of journey"' (Tyler, 1987, p. 140).

\section{Acknowledgement}

This article began as an attempt to answer a challenge that Michael Apple addressed to me in 1987, that is, to think through the implications of ethnography trying to document "nonevents." Mary Darmanin and Peter Serracino Inglott helped by referring me to relevant sources in the sociology of literature and the philosophical dimensions of "silence."

\section{References}

Belsey, C. (1980). Critical practice. London: Methuen.

Bisseret, N. (1979). Education, class language and ideology. London: Routiedge \&e Kegan Paul.

Burbules, N.C. (1986). Education under siege: a review. Educational Theory, 36, 301-313. 
Clifford, J., \& Marcus, G. (Eds.). (1986). Writing culture: the poetics and politics of ethnography. Berkeley: University of California Press.

Eagleton, T. (1976). Criticism and ideology. London: New Left Books (Verso edition).

Gadamer, H.G. (1979). The problem of historical consciousness. In P. Rabinow \& W.M. Sullivan (Eds.), Interpretive social science: a reade (pp. 103-160). Berkeley: University of California Press.

Giddens, A. (1976). New rules of sociological method. London: Hutchinson.

Giroux, H.A. (1988). Postmodernism and the discourse of educational criticism. Joumal of Education, 170 (3), 5-30.

Gitlin, A., Siegel, M., \& Boru, K. (1989). The politics of method: From leftist ethnography to educational research. International Joumal of Qualitative Studies in Education, 2 (3), 237-253.

Hargreaves, A., \& Woods, P. (Eds.). (1984). Classrooms and staffrooms. Milton Keynes, UK: Open University Press.

Lukacs, G. (1971). History and class consciousness. Cambridge: MIT Press.

Macherey, P. (1978). A theory of literary production. London: Routledge \& Kegan Paul.

McLaren, P. (1988). Schooling the postmodern body: critical pedagogy and the politics of enfleshment. Boston Journal of Education, 170 (3), 53-83.

McLaren, P. (1990). Field relations and the discourse of the other: collaboration in our own ruin. In W.B. Shaffir \& R.A. Stebbins (Eds.), Experiencing fieldwork: an inside view of qualitative research (pp. 149-163). Newbury Park, CA: Sage.

McNeil, L.M. (1987). Contradictions of control. London: Routledge \& Kegan Paul.

Pollard, A. (1984). Ethnography and social policy for classroom practice. In L. Barton \& S. Walker (Eds.), The social crisis and educational research (pp. 171-199). London: Croom Helm.

Reynolds, D. (1980-1981). The naturalistic method of educational and social research - a Marxist critique. Interchange, $11(4), 77-89$.

Rotman, B. (1987). Signifying nothing: the semiotics of zero. London: Macmillan.

Sharp, R. (1982). Self-contained ethnography or a science of phenomenal forms and inner relations. Boston Journal of Education, 164 (1), 48-63.

Shipman, M. (1984). Ethnography and policy. In R. Burgess (Ed.), Field methods in the study of education (pp. 273-282). Lewes, UK; Falmer Press.

Sultana, R.G. (1987). Schooling for work in New Zealand. Unpublished doctoral dissertation, University of Waikato, Hamilton, New Zealand.

Sultana, R.G. (1988). Schooling tomorrow's worker: trade union education in secondary schools. New Zealand Journal of Industrial Relations, 13, 3-20.

Sultana, R.G. (1989). Transition education, student contestation and the production of meaning. British Journal of Sociology of Education, 10 (3), 287-310.

Sultana, R.G. (1990). Gender, schooling and transformation. New Zealand Journal of Educational Studies, 25 (1), 5-25.

Sultana, R.G. (1992). Schooling and the ideological reproduction of workers. Wellington, New Zealand: Institute of Industrial Relations.

Tyler, S. (1985). Ethnography, intertextuality and the end of description. American Journal of Semiotics, 3 (4), 83-98.

Tyler, S. (1987). Post-modern ethnography: from document of the occult to occult document. In J. Clifford \& G.E. Marcus (Eds.), Writing culture (pp. 122-140). Berkeley: University of California Press.

West, G.W. (1984). Phenomenon and form in interactionist and neo-Marxist qualitative educational research. In L. Barton \& S. Walker (Eds.), The social crisis and educational research (pp. 256-285). London: Croom Helm.

Wexler, P. (1987). Social analysis of education: after the new sociology. London: Routledge \& Kegan Paul.

Williams, R. (1976): Marxism and literature. New York: Oxford University Press. 